\title{
PERSEPSI PEMERIKSA TERHADAP IMPLEMENTASI KODE ETIK DI LINGKUNGAN BADAN
} PEMERIKSA KEUANGAN REPUBLIK INDONESIA

\author{
Nissa Hanny Tatiara dan Yuniasih Dwi Astuti \\ Auditor Badan Pemeriksa Keuangan RI \\ Email: nissa_hanny@yahoo.com
}

\section{ARTICLE INFO}

Article History:

Received 17 July 2018

Revised 15 August 2018

Accepted 31 August 2018

\section{JEL Classification}

$\mathrm{H} 83, \mathrm{M} 40, \mathrm{M} 42$

Kata kunci:

Persepsi,

Pemeriksa, dan

Kode etik

\begin{abstract}
ABSTRAK
Dalam pelaksanaan tugasnya yakni pemeriksaan terhadap tanggung jawab pengelolaan Keuangan Negara, pemeriksa hendaknya menjunjung tinggi kode etik pekerjaan demi tercipta efektifitas dan efisiensi pemeriksaan. Dalam rangka menumbuh kembangkan kembali kode etik di lingkungan pemeriksa, pimpinan BPK menerapkan kebijakan penegakan kode etik. Penelitian ini menggunakan analisis diskriptif kualitatif, dengan metode wawancara mendalam untuk mengetahui bagaimana persepsi pemeriksa dalam pelaksanaan kode etik di pekerjaanya. Dengan menggunakan metode analisis implementasi George $C$. Edward III, penelitian ini menemukan beberapa kekurangan pengimplementasian kode etik pemeriksa di BPK. Kekurangan pengimplementasian kode etik dapat berdampak pada kecenderungan kegagalan kebijakan yang sedang berjalan. Penelitian ini memberikan masukan bagi pembuat kebijakan, antara lain hal-hal yang perlu ditingkatkan dan diperhatikan demi keberhasilan program di masa datang.
\end{abstract}

\section{PENDAHULUAN}

\section{Latar Belakang}

Tugas pokok dan fungsi utama pemeriksa BPK adalah melaksanakan tugas pemeriksaan terhadap tanggungjawab pengelolaan Keuangan Negara supaya tidak terjadi kerugian negara atau kecurangan dalam pengelolaannya. Dalam pelaksanaan tugasnya, pemeriksa hendaknya menjunjung tinggi kode etik pekerjaan demi tercipta efektifitas dan efisiensi pemeriksaan. Kasus suap yang menimpa pemeriksa Badan

\footnotetext{
${ }^{1}$ KPK Tetapkan Irjen Kemendes dan Auditor BPK sebagai Tersangka Suap. https://news.detik.com/berita/d-3513000/kpk-
}

Pemeriksa Keuangan (BPK) baru-baru ini, membuka mata para abdi negara dan jajaran pimpinan pada instansi tersebut bahwa masih lemahnya penegakan kode etik pemeriksa, khususnya pemeriksa Laporan Keuangan instansi atau lembaga negara. ${ }^{1}$ Lemahnya penegakan kode etik tersebut membuka peluang kerugian negara, karena tindak penyelewengan penggunaan uang negara untuk memperkaya diri sendiri. Modus korupsi yang paling banyak digunakan pada 2017 yakni penyalahgunaan

tetapkan-irjen-kemendes-dan-auditor-bpk-sebagaitersangka-suap diakses pada 2 Maret 2018 
Nissa Hanny: Persepsi Pemeriksa...

anggaran yang mencapai 154 kasus dan menyebabkan kerugian negara mencapai Rp 1,2 triliun. Kemudian diikuti modus penggelembungan harga atau mark up dan pungutan liar berturut-turut sebanyak 77 kasus dan 71 kasus. Sementara, modus suap tercatat mencapai 42 kasus dengan total nilai suap mencapai Rp 211 miliar $^{2}$.

Dalam rangka menumbuh kembangkan kembali kode etik di lingkungan pemeriksa BPK, pimpinan dan bagian penegakan kode etik (dalam hal ini adalah Inspektorat Utama BPK), menerapkan kebijakan penegakan kode etik yang tujuannya tidak lain adalah untuk meningkatkan kesadaran para pemeriksa dalam menjunjung tinggi kode etik pekerjaan. Kebijakan tersebut dituangkan dalam Peraturan Badan Pemeriksa Keuangan Republik Indonesia Nomor 3 Tahun 2016 tentang Kode Etik Badan Pemeriksa Keuangan, yang bertujuan untuk mewujudkan bukan hanya Anggota BPK saja namun juga pemeriksa yang independen, berintegritas, dan profesional dalam melaksanakan tugas pemeriksaan demi menjaga martabat, kehormatan, citra dan kredibilitas BPK.

\section{Perumusan Masalah}

Berdasarkan latar belakang yang dijabarkan diatas, rumusan masalah yang menjadi inti dari penelitian ini yaitu:

1. Bagaimana persepsi pemeriksa BPK terhadap implementasi kode etik yang telah dilaksanakan?

2. Bagaimana cara atau langkah-langkah yang harus dilakukan supaya kode etik tersebut lebih dapat dijunjung oleh pemeriksa BPK?

\section{Tujuan Penelitian}

Tujuan dari penelitian ini adalah untuk mengetahui strategi apa yang perlu diambil,

\footnotetext{
${ }^{2}$ ICW: Kerugian Negara Akibat Korupsi Meningkat. http://nasional.republika.co.id/berita/nasional/huku
}

khususnya oleh BPK RI untuk meningkatkan kesadaran pemeriksa menerapkan kode etik.

\section{Manfaat Penelitian}

Penelitian ini diharapkan dapat berkontribusi dalam memperkaya literatur mengenai persepsi pemeriksa terhadap implementasi kebijakan penegakan kode etik, hambatan dan strategi dalam meningkatkan kesadaran pemeriksa akan kode etik, serta penulis berharap penelitian ini dapat menjadi sumbangan pemikiran bagi pengambil kebijakan khususnya di instansi Badan Pemeriksa Keuangan Republik Indonesia, dan instansi pemerintah lain pada umumnya.

\section{TINJAUAN PUSTAKA}

Unit analisis pelaksanaan penelitian tentang persepsi pemeriksa terhadap implementasi kode etik di lingkungan BPK RI adalah pemeriksa yang aktif dalam Jabatan Fungisonal Pemeriksa BPK RI. Terdapat beberapa konsep yang perlu didefiniskan untuk menjadi landasan dalam menganalisis masalah-masalah penelitian. Konsep-konsep tersebut anatara lain:

\section{Konsep Persepsi}

Menurut Slameto (2010:102) pengertian persepsi adalah proses yang berkaitan dengan masuknya pesan atau informasi kedalam otak manusia, melalui persepsi manusia terus menerus mengadakan hubungan dengan lingkungannya. Hubungan ini dilakukan lewat inderanya, yaitu indera pengelihat, pendengar, peraba, perasa, dan pencium. Hal penting di dalam pemahaman tentang persepsi adalah adanya rangsangan (stimulus) yang diintegrasikan ke dalam diri individu sehingga membuat adanya umpan balik di dalam sikap (perilaku yang ditampilkan) individu tersebut. Menurut Sarlito Wirawan Sarwono (1983: 89), pengertian Persepsi adalah kemampuan

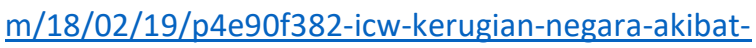
korupsi-meningkat diakses pada 2 Maret 2018 
seseorang untuk mengorganisir suatu pengamatan, kemampuan tersebut antara lain: kemampuan untuk membedakan, kemampuan untuk mengelompokan, dan kemampuan untuk memfokuskan. Oleh karena itu seseorang bisa saja memiliki persepsi yang berbeda, walaupun objeknya sama. Hal tersebut dimungkinkan karena adanya perbedaan dalam hal sistem nilai dan ciri kepribadian individu yang bersangkutan.

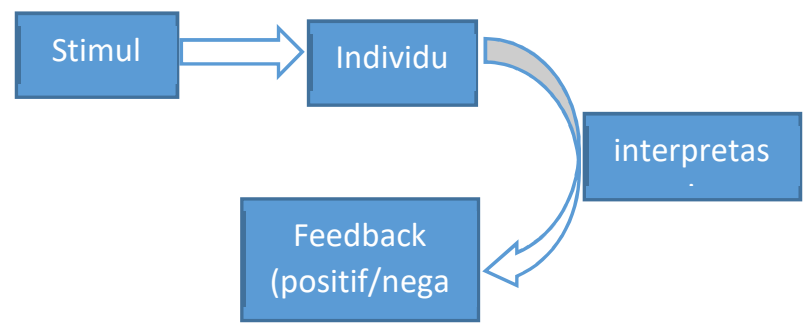

Gambar 1. Model Umpan Balik dalam Sikap Individu

Miftah Toha (2003) menyatakan bahwa faktor-faktor yang mempengaruhi persepsi seseorang adalah sebagai berikut:

1. Faktor internal: perasaan, sikap dan kepribadian individu, prasangka, keinginan atau harapan, perhatian (fokus), proses belajar, keadaan fisik, gangguan kejiwaan, nilai dan kebutuhan juga minat, dan motivasi.

2. Faktor eksternal: latar belakang keluarga, informasi yang diperoleh, pengetahuan dan kebutuhan sekitar, intensitas, ukuran, keberlawanan, pengulangan gerak, hal-hal baru dan familiar atau ketidak asingan suatu objek.

Sedangkan menurut Stephen P. Robbins, (1996) terdapat 3 faktor yang mempengaruhi persepsi seseorang, yaitu:

1. Individu yang bersangkutan (pemersepsi). Apabila seseorang melihat sesuatu dan berusaha memberikan interpretasi tentang apa yang dilihatnya itu, ia akan

menjadi catatan elite jika program tersebut tidak diimplementasikan. Oleh karena itu, dipengaruhi oleh karakterisktik individual yang dimilikinya seperti sikap, motif, kepentingan, minat, pengalaman, pengetahuan, dan harapannya.

2. Sasaran dari persepsi, dapat berupa orang, benda, ataupun peristiwa. Sifat-sifat itu biasanya berpengaruh terhadap pe rsepsi orang yang melihatnya. Persepsi terhadap sasaran bukan merupakan sesuatu yang dilihat secara teori melainkan dalam kaitannya dengan orang lain yang terlibat. $\mathrm{Hal}$ tersebut yang menyebabkan seseorang cenderung mengelompokkan orang, benda, ataupun peristiwa sejenis dan memisahkannya dari kelompok lain yang tidak serupa.

3. Situasi. Persepsi harus dilihat secara kontekstual yang berarti situasi dimana persepsi tersebut timbul, harus mendapat perhatian. Situasi merupakan faktor yang turut berperan dalam proses pembentukan persepsi seseorang.

\section{Implementasi Kebijakan}

Thomas Dye (1992) dalam Said Zainal Abidin (2012) menyebutkan kebijakan sebagai pilihan pemerintah untuk melakukan atau tidak melakukan sesuatu. Menurut William N. Dunn (2000) dalam Syafiie (2006) kebijakan publik adalah suatu rangkaian pilihan-pilihan yang saling berhubungan yang dibuat oleh lembaga atau pejabat pemerintah pada bidang-bidang yang menyangkut tugas pemerintahan seperti pertahanan keamanan, energi, kesehatan, pendidikan, kesejahteraan masyarakat, kriminalitas, perkotaan dan lain-lain. Esensi utama dari kebijakan adalah memahami apa yang seharusnya terjadi sesudah suatu program dinyatakan berlaku atau dirumuskan. Suatu kebijakan tidak akan berarti tanpa implementasi kebijakan, dimana suatu kebijakan hanya akan keputusan program kebijakan yang telah diambil sebagai alternatif pemecahan masalah harus 
Nissa Hanny: Persepsi Pemeriksa...

diimplementasikan, yakni dilaksanakan oleh badan-badan administrasi maupun agen pemerintah ditingkat bawah. Kebijakan yang telah diambil dilaksanakan oleh unit-unit administrasi yang memobilisasi baik finansial maupun manusia.

Dalam perkembangan studi implementasi kebijakan dijelaskan adanya dua pendekatan guna memahami implementasi kebijakan, yaitu pendekatan top down dan bottom up. Pendekatan top down misalnya dapat disebut sebagai pendekatan yang mendominasi awal perkembangan studi implementasi kebijkaan, walaupun kemudian terdapat perbedaanperbedaan sehingga menelurkan pendekatan bottom up, namun pada dasarnya dua pendekatan ini berdasarkan pada asumsi-asumsi yang sama dalam mengembangkan kerangka analisis tentang studi implementasi, yaitu sejauhmana tindakan para pelaksana (administrator dan birokrat) sesuai dengan prosedur serta tujuan yang telah digariskan oleh para pembuat kebijakan.

\section{Model Implementasi Kebijakan Van Metter dan Van Horn}

Model implementasi ini menjelaskan bahwa proses implementasi kebijakan merupakan sebuah abstraksi atau performansi yang pada dasarnya secara sengaja dilakukan untuk meraih kinerja implementasi dan dipengaruhi oleh enam variabel, yaitu: ukuran dan tujuan kebijakan, sumber daya, karakteristik agen pelaksana, sikap dan kecenderungan para pelaksana, kounikasi antarorganisasi dan lingkungan sosial, ekonomi juga politik.

2. Model Implementasi Kebijakan George C. Edward III

George C. Edward III merupakan ilmuwan penganut aliran top down. Nama model implementasi kebijakaan public yang dikembangkan Goerge C. Edward III adalah Direct and Indirect Impact on
Implementation dimana terdapat empat variabel yang sangat menentukan keberhasilan implementasi suatu kebijakan yaitu: (1) Komunikasi, (2) Sumber daya, (3) Disposisi, (4) Struktur birokrasi (Agustino, 2006:149).

Menurut George C. Edward III, komunikasi berkenaan dengan bagaimana kebijakan dikomunikasikan kepada organisasi dan/atau publik dan sikap serta tanggapan dari para pihak yang terlibat. Sedangkan pengertian komunikasi itu sendiri merupakan proses penyampaian informasi dari komunikator kepada komunikan. Komunikasi sangat menentukan keberhasilam pencapaian tujuan dari implementasi kebijakan publik. Implementasi yang efektif terjadi apabila para pembuat keputusan sudah mengetahui apa yang akan mereka kerjakan. Variabel atau faktor kedua yang mempengaruhi keberhasilan implementasi suatu kebijakan adalah sumberdaya. Sumber daya berkenaan dengan ketersediaan sumber daya pendukung, khususnya sumber daya manusia, di mana hal ini berkenaan dengan kecakapan dari pelaksana kebijakan publik untuk menerapkan dan mengimplementasikan kebijakan secara efektif. Disposisi adalah watak dan karakteristik yang dimiliki oleh implementor seperti komitmen, kejujuran dan sifat demokratis. Apabila implementor memiliki disposisi yang baik maka dia akan dapat menjalankan kebijakan dengan baik seperti apa yang diinginkan oleh pembuat kebijakan. Ketika implementor memiliki sikap atau perspektif yang berbeda dengan pembuat kebijakan, maka proses implementasi kebijakan juga akan menjadi tidak efektif. Faktor keempat menurut George Edward III adalah struktur birokrasi. Aspek struktur organisasi ini melingkupi dua hal yaitu mekanisme dan struktur birokrasi itu sendiri. 
Aspek pertama adalah mekanisme, dalam implementasi kebijakan biasanya sudah dibuat Standard Operation Procedure (SOP). Aspek kedua adalah struktur birokrasi, struktur birokrasi yang terlalu panjang dan terfragmentasi akan cenderung melemahkan pengawasan dan menyebabkan prosedur birokrasi yang rumit dan kompleks yang selanjutnya akan menyebabkan aktivitas organisasi menjadi tidak fleksibel.

3. Model Implementasi Kebijakan Daniel Mazmanian dan Paul Sabatier

Model implementasi kebijakan yang dikemukakan oleh Mazmanian dan Sabatier disebut dengan A Framework for Policy Implementation Analysis. Model ini berpendapat bahwa peran penting dari implementasi kebijakan publik adalahkemampuannya dalam mengidentifikasikan variabel-variabel yang mempengaruhi tercapainya tujuan-tujuan formal pada keseluruhan proses implementasi. Variabel-variabel yang dimaksud dapat diklasifikasikan menjadi tiga kategori besar, yaitu:

1. Mudah tidaknya masalah yang akan digarap, meliputi: kesukaran-kesukaran teknis, keberagaman perilaku yang diatur, tingkat dan ruang lingkup perubahan perilaku yang dikehendaki;

2. Kemampuan kebijakan menstruktur proses implementasi secara tepat;

3. Faktor-faktor diluar undang-undang yang mempengaruhi implementasi.

\section{Kode Etik}

\section{Pengertian Kode Etik}

Kode etik pada prinsipnya merupakan sistem dari prinsip-prinsip moral yang diberlakukan suatu kelompok profesi yang ditetapkan secara bersama dan harus dipatuhi oleh setiap mereka yang menjalankan tugas profesi tersebut. Kode etik profesi bersifat mengikat semua anggota profesi dan dalam penetapannya perlu ditetapkan secara bersama. Tanpa kode etik, maka setiap individu dalam satu komunitas akan memiliki tingkah laku yang berbeda-beda yang dinilai baik menurut anggapannya dalam berinteraksi dengan masyarakat lainnya.

Kode etik atau aturan perilaku dibuat sebagai pedoman dalam perilaku atau melaksanakan penugasan sehingga menumbuhkan kepercayaan dan memelihara citra organisasi di mata masyarakat. Kepercayaan masyarakat dan pemerintah atas hasil kerja pemeriksa ditentukan oleh keahlian, independensi, dan integritas auditor dalam menjalankan pekerjaannya. Dengan adanya kode etik, masyarakat akan dapat menilai sejauh mana seorang auditor telah bekerja sesuai dengan standar-standar etika yang telah ditetapkan oleh profesinya (Trisnaningsih, 2007: Sukriah dkk, 2009).

Menurut Chasin, et al (1988) yang dikutip oleh Enjel (2006), mendefinisikan kode etik profesional sebagai berikut:

"Code of professional ethics is guide to accountant conduct in fulfilling the professional obligations and in activities, affect the public's view of the profesions".

Dengan demikian dapat disimpulkan, kode etik profesional adalah pernyataan-pernyataan yang digunakan sebagai haluan perilaku dalam melaksanakan tanggungjawab profesinya.

\section{Tujuan Kode Etik}

Kode etik dibuat dengan tujuan untuk mengatur tingkah laku individu agar sesuai dengan kebutuhan masyarakat, pelanggaran kode etik yang dilakukan oleh seseorang dari anggota profesi tertentu dapat menyebabkan berkurangnya rasa kepercayaan masyarakat terhadap suatu profesi secara keseluruhan.

Menurut Ernawan (2007), tujuan dibuatnya kode etik untuk menunjang martabat 
Nissa Hanny: Persepsi Pemeriksa...

profesi atau memelihara kesejahteraan para anggotanya dengan mengadakan laranganlarangan untuk melakukan perbuatan-perbuatan yang akan merugikan kesejahteraan material para anggotanya. Sehingga maksud yang terkandung dalam pembentukan kode etik yaitu:

1. Menjaga dan meningkatkan kualitas moral

2. Menjaga dan meningkatkan kualitas keterampilan teknis

3. Melindungi kesejahteraan materiil dari para pengemban profesi.

\section{Kode Etik Badan Pemeriksa Keuangan Republik Indonesia (BPK RI)}

Etika profesi akuntan di Indonesia diatur dalam Kode Etik Akuntan Indonesia. Kode etik ini mengikat para anggota Ikatan Akuntan Indonesia dan dapat dipergunakan oleh akuntan yang bukan atau belum menjadi anggota Ikatan Akuntan Indonesia (IAI). Di Indonesia, penegakan kode etik dilaksanakan sekurang-kurangnya enam unit organisasi, yaitu:

1. Kantor Akuntan Publik

2. Unit Peer Review Kompartemen Akuntan Publik-IAI

3. Badan Pengawas Profesi Kompartemen Akuntan Publik-IAI

4. Dewan Pertimbangan Profesi IAI

5. Departemen Keuangan RI

6. Badan Pemeriksa Keuangan.

Selain keenam unit organisasi diatas, pengawasan terhadap kode etik juga dapat dilakukan sendiri oleh para pimpinan KAP.

Kebijakan mengenai kode etik bagi pemeriksa BPK RI tertuang dalam Peraturan Badan Pemeriksa Keuangan Republik Indonesia Nomor 3 Tahun 2016 Tentang Kode Etik Badan Pemeriksa Keuangan. Dalam peraturan tersebut dijelaskan bahwa kode etik BPK yang selanjutnya disebut kode etik adalah norma-norma yang seharusnya dipatuhi oleh setiap Anggota BPK dan Pemeriksa selama menjalankan tugasnya untuk menjaga martabat, kehormatan, citra dan kedibilitas BPK. Adapun faktor-faktor yang terdapat didalamnya antara lain:

\section{Maksud dan Tujuan}

Kode etik bertujuan untuk mewujudkan Anggota BPK dan pemeriksa yang independen, berintegritas, dan profeional dalam melaksanakan tugas pemeriksaan demi menjaga mertabat, kehormatan, citra dam kredibilitas BPK.

\section{Sasaran}

Sasaran dari kode etik ini adalah Anggota BPK dan Pemeriksa. Pemeriksa yang dimaksud adalah Pegawai Negeri Sipil pada Pelaksana BPK, Pegawai Negeri Sipil dari Aparat Pengawas Internal Pemerintah, dan Akuntan Publik yang bekerja atas nama BPK.

\section{Mekanisme}

Mekanisme penerapan kode etik ini diwujudkan dalam sikap, ucapan dan perbuatan Anggota BPK dan pemeriksa dalam melaksanakan tugasnya, khususnya dalam tugas pemeriksaan terhadap pertanggungjawaban keuangan negara/daerah.

\section{Pengawasan dan Pelaporan}

Pengawasan dan pelaporan difokuskan pada apa saja yang akan dilakukan oleh pemeriksa sebagai sasaran kebijakan dalam menerapkan kode etik, peran Inspektorat Utama (Itama) dalam rangka pengawasan, dan cara Itama melaporkan hasil pengawasannya.

\section{Larangan dan sanksi}

Larangan dan sanksi terkait dengan kode etik terkait dengan bentuk pelanggaran yang dilakukan pemeriksa, bentuk pelanggaran yang dilakukan pihak Itama dalam implementasi kode etik dan tindakan BPK dalam menanggulangi pelanggaran yang terjadi serta tanggapan dan tindakan Itama dalam menghadapi pelanggaran yang terjadi dalam implementasi kode etik BPK. 


\section{Kerangka Pikir}

Kerangka pikir dalam suatu penelitian dibutuhkan sebagai pedoman dalam melakukan kajian analisis, teori dan data empiris yang dijumpai dan akan dikembalikan pada alur pikir yang telah ditetapkan. Kerangka pikir penelitian ini merupakan hasil telaahan dari teori persepsi sebagaimana pendapat Stephen P. Robins,
(1996), dan teori implementasi kebijakan George C. Edward III untuk saling melengkapi dalam menelaah masalah penelitian. Penelitian yang berjudul "Persepsi Pemeriksa Terhadap Implementasi Kode Etik Di Lingkungan Badan Pemeriksa Keuangan Republik Indonesia", menggunakan alur pikir seperti yang tergambar dibawah ini:
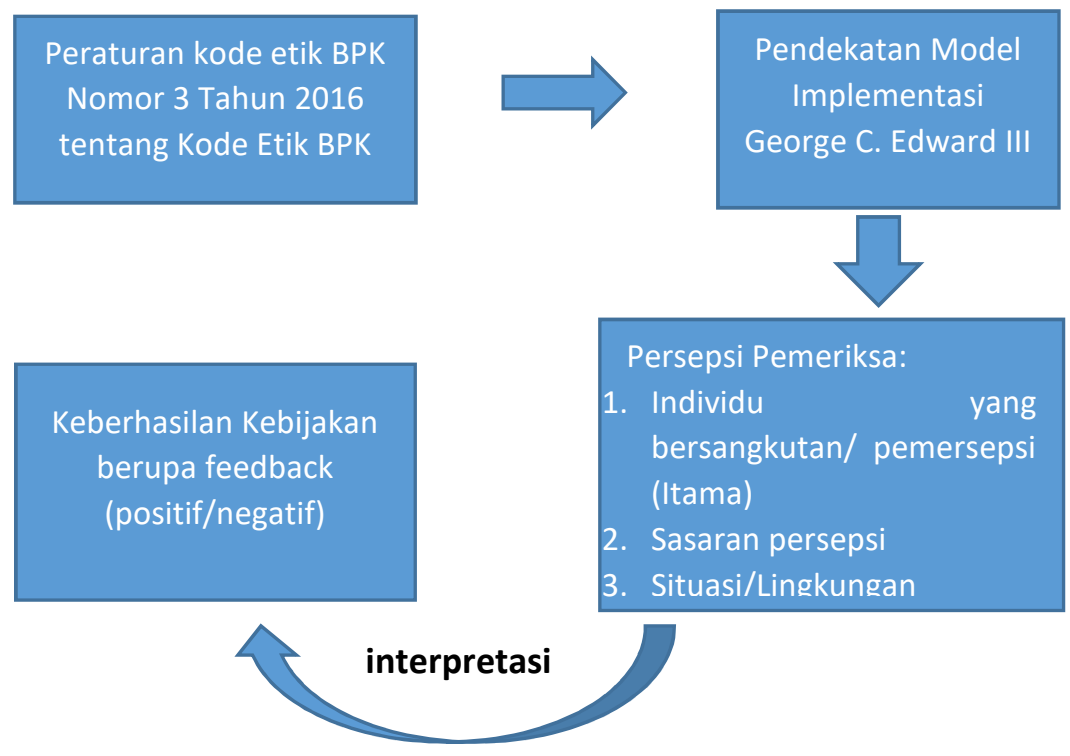

Gambar 2. Skema Kerangka Pikir Penelitian

\section{METODE PENELITIAN \\ Desain Penelitian}

Penelitian ini memberikan gambaran metode yang aktual dengan jalan mengumpulkan data, menyusun, menganalisis data dan menginterpretasikannya. Metode yang digunakan adalah metode deskriptif dengan teknik pendekatan secara kualitatif. Bogdan dan Taylor (1992) dalam Moleong (2010) mengatakan bahwa prosedur penelitian yang menghasilkan data deskriptif berupa kata-kata tertulis atau lisan dari orang-orang dan perilaku yang diamati disebut metodologi kualitatif. Penelitian ini menggunakan metode kualitatif dengan mengumpulkan sebanyak-banyaknya data/informasi mengenai persepsi pemeriksa terhadap pengimplementasian kode etik di lingkungan kantor Badan Pemeriksa Keuangan Republik Indonesia. Selain itu, melalui pengumpulan informasi tersebut diharapkan juga mampu terindikasi faktor-faktor yang mempengaruhi pelaksanaan kode etik pemeriksa BPK RI.

\section{Teknik Pengumpulan Data}

Menurut Rubino (2009:73) wawancara adalah teknik pengumpulan data dengan jalan tanya jawab secara langsung berhadapan muka, peneliti bertanya secara lisan dan responden 
Nissa Hanny: Persepsi Pemeriksa...

menjawab secara lisan pula. Ada beberapa bentuk wawancara yaitu:

1. Wawancara terstruktur adalah apabila peneliti sebagai pewawancara sudah mempersiapkan bahan wawancara terlebih dahulu;

2. Wawancara tidak terstruktur adalah bentuk wawancara dimana prakarasa untuk memilih topik bahasan diambil oleh siswa atau orang yang diwawancarai (Kunandar, 2010:159160).

Teknik pengumpulan data pada penelitian ini menggunakan teknik wawancara terstruktur dengan untuk mengetahui tanggapan pihal pengimplementasi program, yakni Inspektorat Utama dan pemeriksa BPK. Wawancara kepada pihak pengimplementasi kebijakan berguna untuk mengetahui bagaimana kebijakan dilaksanakan oleh pemeriksa, diawasi dan dievaluasi oleh Itama, dan untuk memperoleh persepsi pemeriksa mengenai kelebihan, kekurangan dan masukan kebijakan kedepannya.

\section{Teknik Analisis Data}

Teknik analisis data yang digunakan adalah analisis domain. Teknik analisisi ini digunakan untuk memperoleh gambaran/pengertian yang bersifat umum dan relatif menyeluruh tentang apa yang tercakup di suatu fokus/pokok permasalahan yang tegah diteliti. Metode analisis domain digunakan untuk memperoleh gambaran menyeluruh mengenai faktor-faktor yang mempengaruhi penerpan kode etik berdasarkan persepsi responden. Persepsi yang dikaji dalam penelitian ini dibatasi pada mekanisme pengimplementasian kebijakan dan keberhasilan program dalam menumbuhkembangkan kode etik pemeriksa BPK.

\section{ANALISIS DAN PEMBAHASAN \\ Pengumpulan Data}

Pengumpulan data dalam penelitian ini dilakukan dengan wawancara kepada responden. Kriteria responden yang dijadikan sampel dalam peneliatian ini adalah pemeriksa/auditor BPK yang ditempatkan pada fungsional pemeriksa atau yang berada pada unit kerja Auditorat Keuangan Negara dan pemeriksa yang berada pada unit kerja Inspektorat Utama pada sub bagian Penegakan Integritas. Jumlah responden yang berada pada unit kerja Auditorat adalah sebanyak 20 orang, sedangkan responden pada Itama adalah sebanyak 10 orang.

\section{Implementasi Kode Etik Pemeriksa di Badan Pemeriksa Keuangan (BPK RI)}

\section{Komunikasi}

Dari hasil wawancara terhadap 20 orang responden pemeriksa BPK, didapatkan hasil bahwa proses komunikasi yang dibangun oleh pihak yang bertanggungjawab pengawasan kebijakan kode etik dalam hal lini adalah Inspektorat Utama telah dilaksanakan. Informasi mengenai peraturan kode etik, batasan-batasan, dan larangannya sudah diketahui oleh pemeriksa, melalui beberapa metode pengkomunikasian dari Itama yakni berupa surat edaran, sosialisasi-sosialisasi verbal maupun tulisan, hingga pembuatan pakta integritas masing-masing pemeriksa yang diperbaharui tiap tahun.

Tujuan dari Itama dalam melakukan sosialisasi tersebut adalah agar pemeriksa tujuan utama kebijakan dapat tercapai yaitu pemeriksa mampu bekerja secara profesional, berintegritas dan independen. Proses komunikasi secara berjenjang dari pucuk pimpinan tertinggi hingga terendah pun sudah dilaksanakan, hanya saja belum dapat sepenuhnya sesuai ketentuan, sesuai yang dikemukakan oleh beberapa responden: 
"Penerapan kode etik dapat dilaksanakan tapi tidak bisa $100 \%$ sesuai ketentuan, karena beberapa auditor memang sebenarnya sudah tahu batasannya namun tetap saja melanggar karena kurangnya kesadaran diri sendiri"

(Tanggapan MA, Pemeriksa BPK, Mei 2018)

"Informasi dan komunikasi pimpinan terkait kode etik sudah cukup memadai, mulai dari sosialisasi sampai pengarahan langsung sebelum berangkat tugas, tapi semua kembali ke masingmasing dalam menjaga kode etik tersebut tetap dijalankan atau tidak".

(Tanggapan AY, Pemeriksa BPK, Mei 2018)

Inspektorat Utama (Itama) sendiri berpendapat bahwa selama ini Itama telah berusaha semaksimal mungkin dalam proses pengkomunikasian kebijakan tersebut. Salah satu langkah terbaru adalah dengan diluncurkannya aplikasi daring untuk mengungkapkan pelanggaran kode etik yang dilakukan oleh pemeriksa dengan nama Whistle Blowing System (WBS) dan Program Pengendalian Gratifikasi (PPG) BPK yang dikelola oleh Itama, pada bulan Juni 2017. Tujuan dari aplikasi tersebut adalah untuk mengungkapkan kecurangan pemeriksa khususnya pelanggaran kode etik agar dapat segera ditindaklanjuti.

"Aplikasi ini (WBS dan PPG) akan membantu para pegawai BPK apabila diketahui dalam pelaksanaan tugas ada kesadaran diri pegawai BPK untuk melaporkan terhadap apa yang dilihat dan diketahui dari perilaku para auditor". (Tanggapan MS, Mantan Inspektur Utama, Mei 2018)

Pemanfaatan teknologi informasi ini diharapkan semakin mempermudah bagi pemeriksa maupun non pemeriksa untuk mengungkapkan kecurangan yang dilakukan oleh pemeriksa, tanpa harus takut diketahui identitasnya oleh pelaku. Dari hasil wawancara juga ditemukan bahwa semua responden telah mengetahui bahwa BPK telah memiliki sistem tersebut, hanya saja sebagian besar dari mereka belum pernah menggunakan, bahkan belum pernah mencoba membuka laman tersebut. Namun secara garis besar responden merespon positif terhadap proses komunikasi yang dibangun oleh Itama dalam penegakan kode etik pemeriksa BPK.

\section{Sumber Daya}

Dalam penerapan kebijakan kode etik, BPK RI berusaha memaksimalkan sumber daya yang tersedia terutama dalam memfasilitasi pemeriksa maupun masyarakat diluar BPK yang menemukan tindak pelanggaran kode etik apabila akan melakukan pengaduan. Pemanfaatan dan penggunaan sumber daya dalam implementasi kebijakan tersebut antara lain dengan:

a. Pengalokasian anggaran khusus terkait penerapan kode etik, mulai dari proses perencanaan, implementasi hingga evaluasi kebijakan. Dari hasil wawancara dengan responden diketahui bahwa BPK RI telah menganggarkan biaya untuk pelaksanaan kebijakan kode etik ini dalam Rencana Kerja dan Anggaran Kementerian Negara/Lembaga (RKA-KL) tiap tahun anggaran. Tujuannya adalah untuk menyediakan rencana terinci mengenai aktivitas dengan maksud mengurangi ketidakpastian dan memberikan pengarahan yang jelas kepada seluruh jajaran Itama khususnya sub bagian penegakan integritas dalam mencapai tujuan kebijakan.

"Itama mendapatkan alokasi anggaran untuk penegakan kode etik untuk menunjang teman-teman PI (Penegakan Integritas) menjalankan tugasnya lebih maksimal. misalnya untuk sosialisasi ke temen-temen auditor, untuk ngelola aplikasi, buat jalan kalau ada pengaduan dII" 
Nissa Hanny: Persepsi Pemeriksa...

(Tanggapan IS, Inspektur Utama, Mei 2018)

"Dukungan dari atasan khususnya untuk pencairan anggaran kegiatan pemantauan pelaksanaan kode etik menurut saya penting ya untuk rekan-rekan itama, biar mereka kerjanya juga enak, soalnya kan kegiatankegiatan seperti sosialisasi, sidak ke lapangan dll butuh biaya juga"

(Tanggapan IR, Pelaksana pada Itama, Mei 2018)

"Untuk pengelolaan sistem online, kita juga butuh banyak biaya ya, untuk maintenance, untuk tindak lanjutnya, juga untuk pengelolanya juga"

(Tanggapan Ang, Pelaksana pada Itama, Mei 2018)

b. Pembuatan SOP/Standar Operasional Prosedur, yakni dalam hal pengaduan dan tindak lanjut terhadap indikasi pelanggaran kode etik pemeriksa. SOP dibuat sebagai standarisasi cara yang dilakukan pegawai dalam menyelesaikan pekerjaan yang menyelesaikan tugasnya, untuk mengurangi tingkat kesalahan dan kelalaian yang mungkin dilakukan oleh seorang pegawai dalam melaksanakan tugas, serta menciptakan ukuran standar kinerja yang akan memberikan pegawai cara konkrit untuk memperbaiki kinerja serta membantu mengevaluasi usaha yang telah dilakukan.

c. Pembentukan majelis kehormatan kode etik, yang bertugas untuk melakukan kajian dan penyelidikan terhadap pengaduan pelanggaran kode etik. Anggota Majelis Kehormatan Kode Etik terdiri dari unsur pimpinan tinggi BPK dan dari unsur profesi diluar lembaga. Keanggotaan Majelis terbaru disahkan dengan Keputusan BPK Nomor 16/K/I-XIII.2/10/2017 tentang Pengangkatan Anggota Majelis Kehormatan Kode Etik Badan Pemeriksa Keuangan Tahun 2017 s.d.
2019. Susunan Majelis Kehormatan Kode Etik berdasarkan Keputusan tersebut antara lain Dr. Agus Joko Pramono, S.ST., M.Acc., Ak. C.A. (Ketua merangkap anggota), Ir. Isma Yatun, M.T., (anggota MKKE), keduanya dari unsur pimpinan tinggi BPK, serta Prof, Zaki Baridwan, M.Sc., PhD., Ak., CA., Prof. Dr. I Gde Pantja Astawa, S.H., M.M., dan Dr. Jusuf Halim, S.E., Ak., M.H., CA. yang merupakan unsur profesi dan akademis. Tujuan dari pembentukan MKKE dari beberapa unsur adalah selain untuk tetap menjaga independensi anggota majelis, juga untuk memberikan masukan yang lebih baik bagi pimpinan khususnya anggota MKKE secara disiplin ilmu yang dimiliki masing-masing.

\section{Disposisi}

Disposisi adalah watak dan karakteristik yang dimiliki oleh implementor seperti komitmen, kejujuran dan sifat demokratis. Apabila implementor memiliki disposisi yang baik maka dia akan dapat menjalankan kebijakan dengan baik seperti apa yang diinginkan oleh pembuat kebijakan. Ketika implementor memiliki sikap atau perspektif yang berbeda dengan pembuat kebijakan, maka proses implementasi kebijakan juga akan menjadi tidak efektif. Tanggapan salah satu responden mengenai unsur disposisi dalam penegakan kode etik ini adalah:

"Penerapan kode etik masih beragam, namun menurut saya contoh dari para pimpinan BPK sangat mempengaruhi penerapan kode etik. Insya Allah jika para pemimpin memilikikomitmen yang sama terhadap penerapan kode etik, para bawahan dan pelaksana BPK akan mengikuti, atau setidaknya akan berpikir dua kali untuk melakukan pelanggaran"

(Tanggapan AW, Jakarta, Mei 2018)

"Secara umum di BPK belum sepenuhnya dilaksanakan dengan baik dan maksimal. Masih 
ditemukan adanya pelanggaran-pelanggaran oleh pemeriksa dan juga pimpinan dalam penerapan kode etik dan beberapa diantaranya sudah terpublikasi di media massa dan ranah pengadilan".

(Tanggapan NKS, Jakarta, Mei 2018)

Sebagian besar responden merespon dan beranggapan bahwa faktor disposisi dari terkait penerapan kode etik menjadi hal yang penting dalam keberhasilan kebijakan tersebut. Hanya saja dalam hal ini, beberapa responden menilai bahwa implementator belum sepenuhnya menerapkan faktor disposisi dalam penegakan kode etik.

"Kebijakan penerapan kode etik semestinya dilaksanakan seluruh pihak di BPK dimulai dari pimpinan teratas sampai yang paling bawah, dengan pengawasan oleh dua arah, dari atas dan dari bawah"

(Tanggapan MA, Jakarta, Mei 2018)

"Seharusnya dilaksanakan secara adil dan merata, artinya apabila ada pemeriksa yang terbukti melanggar kode etik beri hukumana yang benar-benar membuat orang jera dan jangan memberi celah pemeriksa maupun pelaksana yang lainnya untuk melaakaukan hal yang sama. Satu lagi jangan pernah menjadikan mereka pejabat apabila sudah pernah kena hukuman pelanggaran kode etik".

(Tanggapan RDS, Jakarta, Mei 2018)

Pendisposisian wewenang dan tanggungjawab dari pembuat kebijakan ke pelaksana kebijakan menjadi hal yang sangat penting terkait keberhasilan suatu program/kebijakan. Komitmen, tanggungjawab, dan kesadaran implementator menjadi sangat penting dalam keberhasilan suatu kebijakan, dan menurut

\footnotetext{
${ }^{3}$ Etika dan Integritas Auditor Dipertanyakan. http://jateng.tribunnews.com/2017/06/02/etika-
}

sebagian besar responden, tugas dari pimpinan untuk menumbuhkan sikap tersebut dinilai belum terlaksana dengan maksimal karena fakta di lapangan masih ditemukannya pelanggaran terhadap kode etik pemeriksa hingga harus dibawa ke ranah hukum ${ }^{3}$.

\section{Struktur Birokrasi}

Aspek struktur organisasi ini melingkupi dua hal yaitu mekanisme dan struktur birokrasi itu sendiri. Aspek pertama adalah mekanisme, dalam implementasi kebijakan biasanya sudah dibuat Standard Operation Procedure (SOP). Dalam Peraturan BPK Nomor 4 Tahun 2016 Bab V Pasal 21-29 dijelaskan bahwa tahapan-tahapan terjadinya pengaduan indikasi pelanggaran kode etik adalah sebagai berikut:

dan-integritas-auditor-dipertanyakan diakses pada 2 April 2018 
Nissa Hanny: Persepsi Pemeriksa...

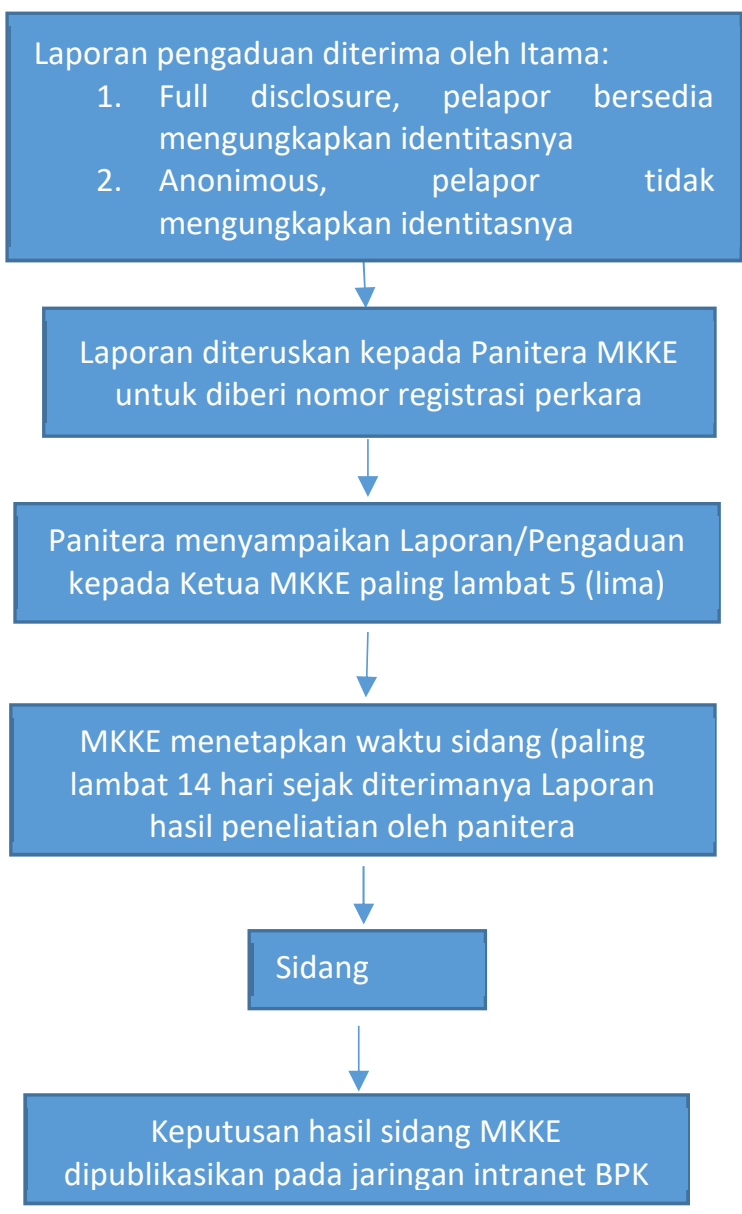

Gambar 3. Tahapan Terjadinya Pengaduan Indikasi Pelanggaran Kode Etik

Prosedur ini harus ditaati dan dipatuhi demi proses penegakan kode etik yang lebih baik bagi pemeriksa BPK. Selama ini SOP yang berlaku belum pernah terindikasi dilanggar/tidak dilakukan, baik oleh bagian penegakan integritas, panitera, maupun MKKE.

"Penyelenggaraan sidang MKKE untuk menindaklanjuti pengaduan pelanggaran selama ini telah dilakukan dengana baik demi menegakkan peraturan kode etik dengan memanfaatkan sumber daya yang kami miliki" (Tanggapan IS, Inspektur Utama BPK, Mei 2018)
Aspek kedua adalah struktur birokrasi, struktur birokrasi yang terlalu panjang dan terfragmentasi akan cenderung melemahkan pengawasan dan menyebabkan prosedur birokrasi yang rumit dan kompleks yang selanjutnya akan menyebabkan aktivitas organisasi menjadi tidak fleksibel. BPK dalam hal telah berusaha melakukan perampingan struktur dan birokrasi terkait pengaduan terhadap pelanggaran kode etik pemeriksa. Sehingga tindaklanjut terhadap indikasi pelanggaran tersebut dapat berjalan dengan efektif dan efisien, serta tepat sasaran.

\section{Persepsi Pemeriksa terhadap Sasaran Penerapan Kode Etik}

Sesuai Peraturan BPK Nomor 3 Tahun 2016 pasal 3, sasaran kode etik antara lain Anggota BPK dan Pemeriksa. Pemeriksa adlaah orang yang melaksanakan tugas pemeriksaan pengelolaan dan tanggungjawab keuangan negara untuk dan atas nama BPK. Penerapan kode etik merupakan kebijakan untuk menanamkan nilai-nilai dasar BPK yaitu Integritas, Independensi Profeionalisme (IIP), dan harus dipatuhi dalam rangka menjaga martabat, kehirmatan, citra dan kredibilitas BPK. Dalam penelitian ini akan dinilai bagaimana persepsi pemeriksa dalam menerima dan melaksanakan kebijakan sehingga mampu dijadikan masukan bagi pembuat kebijakan sebagai evaluasi.

\section{Persepsi Pemeriksa terhadap Kepatuhan Menaati Kode Etik}

Dari hasil wawancara kepada responden pemeriksa, didapatkan hasil bahwa persepsi pemeriksa terhadap kepatuhan menaati kode etik sudah cukup baik, hanya masih ada sekitar $25 \%$ dari responden yang berpendapat sebaliknya karena faktor punishment yang diterapkan bagi pelanggar kode etik selama ini belum memberikan efek jera bagi pelanggarnya.

"Kurang greget, karena pejabat yang pernah dikenai sanksi masih bisa promosi. Dan sanksi 
bagi pegawai maupun pelaksana yang melanggar kode etik pun tidak mengakibatkan jera sehingga masih dan akan ada yang melanggar kode etik".

(Tanggapan RDS, Jakarta, Mei 2018)

"Tingkat kepatuhan belum 100\% sesuai kode etik"

(Tanggapan MA, Jakarta, Mei 2018)

Tanggapan diatas adalah contoh persepsi negatif dari responden terkait kepatuhan pemeriksa terhadap kode etik. Sedangkan sebagian besar responden menyatakan bahwa persepsi pemeriksa terhadap kepatuhan menaatai kode etik sudah memadai, seperti yang disampaikan berikut ini:

"Sampai saat ini, tingkat kepatuhan pemeriksa dalam melaksanakan kode etik sudah cukup memadai".

(Tanggapan NKS, Jakarta, Mei 2018)

"Respon kami terhadap pelaksanaan kode etik baik, dan siap melaksanakan sesuai prosedur". (Tanggapan dari AW, Jakarta, Mei 2018)

"Saya hanya mengetahui kondisi di unit kerja saya saja, kepatuhan pemeriksa cukup tinggi. Namun saya tidak tahu dengan unit keja yang lain".

(Tanggapan Yul, Jakarta, Mei 2018)

"Pemeriksa cukup mematuhi kode etik" (Tanggapan AY, Jakarta, Mei 2018)

\section{Persepsi Pemeriksa terhadap Masalah yang Dihadapi dalam Penerapan Kode Etik}

Penerapan kode etik ini secara tidak disadari memunculkan satu masalah baru bagi pemeriksa.

"Jika tingkat kepatuhan dan kesadaran penerapan kode etik tinggi, maka akan membawa dampak positif, sebaliknya jika rendah maka akan terjadi pro dan kontra antara yang memiliki prinsip untuk menerapkan dan yang tidak mau menerapkan. Hal ini berpotensi konflik. Selain itu jika pelanggaran kode etik terekspos maka nama BPK sebagai institusi akan tercemar dan hal tersebut berdampak negatif terhadap tingkat kepercayaan masyarakat kepada BPK"

(Tanggapan AW, Pemeriksa BPK, Mei 2018)

"Masalah akan muncul apabila tidak diterapkannya kode etik oleh pemeriksa yaitu adanya kasus seperti berita akhir-akhir ini. Bagaimana opini diperjualbeilkan, walaupun masih menunggu hasil putusan sidang pengadilan namun stigma yang ada di masyarakat BPK bisa disuap. Sungguh ironi bukan? Seharusnya kita sebagai sapu untuk menyapu supaya bersih lantainya, apabila ada stigma negatif tersebut banyak yang menyayangkan"

(Tanggapan RDS, Pemeriksa BPK, Mei 2018)

"Jika belum semua jajaran memiliki komitmen yang sama, peeriksa akan dibebani dengan intervensi-intervensi dalam melaksanakan pemeriksaan. Sebaliknya, jika di suatu unit kerja semua jajaran memiliki komitmen yang sama, makan tidak akan muncul masalah".

(Tanggapan Yul, Pemeriksa BPK, Mei 2018)

Dari ketiga penyataan diatas dapat diindikasikan bahwa permasalah kebijakan akan timbul apabila dari diri pribadi pemeriksa tidak ditanamkan secara utuh kesadaran dalam menjunjung tinggi kode etik pemeriksa. Dan persepsi negatif bahwa kebijakan tersebut tidak akan berjalan dengan baik akan terus ada dalam pemeriksa apabila sistem punishment tidak diberlakukan secara ketat. Pembentukan presepsi negatif tersebut dikarenakan beberapa hal, diantaranya:

\section{a. Faktor internal}


Nissa Hanny: Persepsi Pemeriksa...

Faktor penyebab timbulnya masalah penerapan kode etik pemeriksa dalah berasal dari internal pemeriksa itu sendiri.

"Menurut saya faktor internal dari pemeriksa adalah pemeriksa itu sendiri sulit untuk menolak dan mengatakan tidak, bahkan meminta tanpa malu kepada suditee"

(Tanggapan NKS, Pemeriksa BPK, Mei 2018)

"Menurut saya kendala utama ada dua faktor internal yaitu dari masing-masing individu auditor terkait kesadaran pemeriksa dalam menegakkan kode etik".

(Tanggapan AW, Pemeriksa BPK, Mei 2018)

"Kendala ada jika pihak entitas memiliki hubungan istimewa dengan pimpinan di unit kerja kita. Akan menjadi semakin berat bagi pemeriksa untuk mempertahankan kode etiknya"

(Tanggappan Yul, Pemeriksa BPK, Mei 2018)

Menurut tanggapan ketiga pemeriksa diatas, faktor internal dalam diri pemeriksa menjadi faktor penyebab timbulnya masalah dalam penerapan kode etik. Konflik dalam diri pribadi pemeriksa akan menjadi penghalang bagi dirinya untuk tetap independen dan profesional terutama dalam menghadapi pihak eksternal yaitu auditee.

\section{b. Faktor eksternal}

Dari wawancara responden (pemeriksa), persepsi mereka terhadap masalah yang timbul dari penerapan kode etik ini akibat dari faktor eksternal yaitu lingkungan kerja pemeriksa.

"Kendala dalam pelaksanaan kebijakan ini antara lain lingkungan yang tidak memungkinkan untuk menerapkan kode etik, misalnya pemeriksaan lapangan dengan kondisi ekstrim yang tidak didukung dengan biaya kendaraan dan keamanan yang cukup sehingga harus menerima bantuan auditee"

(Tanggapan MA, Pemeriksa BPK, Mei 2018)

"Jika terlalu ketat menerapkan kode etik yang ada, hubungan antara pemeriksa dengan auditee menjadi terlalu kaku dan formal sehingga terkadang menyulitkan pemeriksa untuk mendapatkan data dan informasi".

(Tanggapan AY, Pemeriksa BPK, Mei 2018)

"Pihak auditee yang mencoba untuk mempengaruhi pemeriksa untuk melakukan pelanggaran kode etik serta masih adanya stigma adat ketimuran terkait "ewuh pakewuh" yang jika tidak diterima oleh pemeriksa berpengaruh terhadap perolehan data dan informasi". (Tanggapan NKS, Pemeriksa BPK, Mei 2018)

Hampir seluruh responden yang diwawancarai mengungkapkan bahwa kedua faktor tersebut baik internal maupun eksternal saling berkaitan satu sama lain. Ketika lingkungan memberikan tekanan bagi pemeriksa untuk melanggar kode etik, maka kembali lagi ke individu-individu pemeriksa tersebut untuk tetap mempertahankan integritasnya masing-masing.

3. Persepsi Pemeriksa terhadap Hasil Penerapan Kebijakan Kode Etik Pemeriksa

Persepsi pemeriksa terhadap hasil penerapan kebijakan diperoleh guna mengetahui sampai sejauh mana pemeriksa terpengaruh dalam melaksanakan tugasnya, apakah sudah 
menerapkan secara menyeluruh kode etik tersebut atau belum, dan bagaimana dampaknya terhadap kredibilitas BPK secara keseluruhan.

Data dari Itama menyebutkan bahwa pelanggaran kode etik terberat pemeriksa adalah kasus suap, dan sejak tahun 2005 s.d. 2017 sedikitnya terdapat 6 kasus suap yang melibatkan 23 pemeriksa BPK. Sebanyak 4 kasus suap terkait mendapatkan opini BPK atas Laporan Hasil Pemeriksaan keuangan, 1 kasus suap untuk mengubah hasil temuan BPK, dan 1 kasus suap agar mengesampingkan temuan yang mencurigakan. Tren terungkapnya kasus penyuapan tersebut tentu membuka mata semua orang terutama BPK bahwa dalam institusi, kode etik pemeriksa belum dilaksanakan secara baik dan benar. Ketika ditanya mengenai hasil penerapan kode etik terhadap pemeriksa, seluruh responden menjawab bahwa kebijkaan tersebut berdampak dan berpengaruh terhadap integritas, independensi dan profesionalisme. Hal ini dikarenakan batasan dan larangan telah ditetapkan secara jelas, hanya saja kekurangannya pada punishment yang kurang mendalam bagi pelanggarnya.

\section{PENUTUP}

\section{Simpulan}

Penelitian ini berjudul "Persepsi Pemeriksa Terhadap Implementasi Kode Etik Di Lingkungan Badan Pemeriksa Keuangan Republik Indonesia". Hasil temuan dan pembahasan terhadap masalah penelitian yang telah dideskripsikan dalam Analisis dan Pembahasan disimpulkan sebagai berikut:

1. Sebagian besar responden (kelompok sasaran), beranggapan bahwa implementasi kode etik pemeriksa sudah baik, dinilai berdasarkan 4 (empat) indikator yakni komunikasi, sumber daya, disposisi dan struktur birokrasi. Dari indikator tersebut, faktor komunikasi, sumber daya dan disposisi perlu diitingkatkan lebih baik, karena memegang peranan yang penting terkait dengan hubungan langsung ke perilaku kelompok sasaran;

2. Persepsi responden terhadap hasil sasaran penerapan kode etik yakni sebesar $90 \%$ menyatakan kode etik yang diterapkan oleh BPK sudah baik, dan sebaliknya hanya $10 \%$ yang menyatakan bahwa sasaran penerapan kurang baik karena hanya menyasar pada pemeriksa secara "tebang pilih" dan masih lemahnya hukuman yang diterima oleh pelanggar kode etik;

3. Pimpinan BPK sebagai pihak pembuat kebijakan belum memperhatikan dampak negatif yang muncul akibat kode etik tersebut. Sehingga dapat disimpulkan bahwa menerapan kode etik pemeriksa dapat berjalan dengan maksimal apabila masingmasing dari implementor mampu memaksimalkan tugas pokok dan fungsi masing-masing, sesuai faktor-faktor pendukung keberhasilan pengimplementasian kebijakan pada poin 1. Saran

Penelitian ini menemukan beberapa kekurangan pengimplementasian kode etik pemeriksa di BPK sebagaimana yang telah disimpulkan pada bagian kesimpulan. Kekurangan pengimplementasian kode etik dapat berdampak pada kecenderungan kegagalan kebijakan yang sedang berjalan. Berikut ini disarankan beberapa hal yang setidaknya dapat menjadi masukan bagi pimpinan BPK selaku pembuat kebijakan.

1. Memberikan reward and punishment secara jelas dan tidak pilih-pilih baik kepada pelanggar kode etik, maupun penghargaan kepada pegawai BPK yang telah berani mengungkapkan pelanggaran kode etik yang terjadi di lingkungannya;

2. Memberikan solusi terhadap kendala yang ditemui pemeriksa di lapangan ketika harus 
Nissa Hanny: Persepsi Pemeriksa...

menegakkan kode etik pemeriksa, yakni peningkatan terhadap fasilitas pemeriksa seperti kesehatan dan penunjang pemeriksaan seperti transportasi yang memadai, sehingga pemeriksa tidak perlu bergantung kepada auditee dan dapat mempertahankan independensinya tanpa merusak hubungan profesional dengan auditee.

\section{DAFTAR PUSTAKA}

Abidin, Said Z. (2012). Kebijakan Publik. Jakarta: Salemba Humanika.

Agustino, L. (2006). Dasar-dasar Kebijakan Publik. Bandung: CV. Alfabeta.

Anton. (2017). Etika dan Integritas Auditor Dipertanyakan. Tersedia di http://jateng.tribunnews.com/2017/06/0 2/etika-dan-integritas-auditordipertanyakan

Enjel, B. (2006). Hubungan antara Penerapan Aturan Etika dengan Peningkatan Profesionalisme Auditor Internal. Fakultas Ekonomi. Universitas Widyatama. Bandung. Skripsi yang tidak dipublikasikan

Ernawan, Erni R. (2007). Business Ethics. Bandung: CV. Alfabeta.

Fatmawati, Nur I. (2017). KPK Tetapkan Irjen Kemendes dan Auditor BPK sebagai Tersangka Suap. Tersedia di https://news.detik.com/berita/d3513000/kpk-tetapkan-irjen-kemendesdan-auditor-bpk-sebagai-tersangka-suap.

Kunandar. (2010). Langkah Mudah Penelitian Tindakan Kelas Sebagai Pengembangan Profesi Guru. Jakarta: PT Raja Grafindo Persada.

Moleong, Lexy J. (2010). Metode Penelitian Kualitatif. Bandung: Remaja Rosdakarya

Nandari, Ade Wisteri S. (2015). Pengaruh Sikap Skeptis, Independensi, Penerapan Kode Etik, dan Akuntabilitas terhadap Kualitas
Audit. E-Jurnal Akuntansi Univ. Udayana. Vol. 10.1.

Peraturan Badan Pemeriksa Keuangan Republik Indonesia Nomor 3 Tahun 2016 Tentang Kode Etik Badan Pemeriksa Keuangan.

Peraturan Badan Pemeriksa Keuangan Republik Indonesia Nomor 4 Tahun 2016 Tentang Majelis Kehormatan Kode Etik Badan Pemeriksa Keuangan.

Rubiyanto, R. (2009). Metode Penelitian Pendidikan. Surakarta: UMS.

Robbins, Stephen P. (2003). Perilaku Organisasi. Jakarta: Index.

Saputri, Dessy S. (2018). ICW: Kerugian Negara Akibat Korupsi Meningkat. Tersedia di http://nasional.republika.co.id/berita/nasi onal/hukum/18/02/19/p4e90f382-icwkerugian-negara-akibat-korupsimeningkat

Sarwono, Sarlito W. (1983). Pengantar Umum Psikologi. Jakarta: Bulan Bintang

Slameto. (2010). Belajar dan Faktor-faktor Yang Mempengaruhinya. Edisi revisi. Jakarta: Rhineka Cipta.

Syafiie, Inu K. (2006). Ilmu Administrasi Publik. Jakarta: PT. Rhineka Cipta

Toha, Miftah. (2003). Perilaku Organisasi Konsep Dasar dan Aplikasinya. Jakarta: PT Raya Grafindo Persada

Trisnaningsih, S. (2007). Independensi Auditor dan Komitmen Organisasi Sebagai Mediasi Pengaruh Penanaman Good Governance, Gaya Kepemimpinan, Budaya Organisasi terhadap Kinerja Auditor. Simposium Nasional Akuntansi X. 26-28 Juli, Makassar

Zarefar, A. (2015). The Influence of Ethics, experience and competency toward the quality of auditing with professional auditor skepticism as a Moderating Variable. $3^{\text {rd }}$ Global Conference on Business and Social Science-2015, GCBSS-2015, 1617 December 2015, Kuala Lumpur, Malaysia. 